\title{
Sagittal changes in lower incisors by the use of lingual arch
}

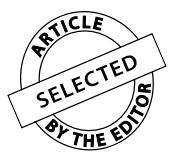

Helen Carolina Becker Letti ${ }^{1}$ Susana Maria Deon Rizzatto², Luciane Macedo de Menezes², Chalana Sangalli Reale³, Eduardo Martinelli de Lima², Fernando Lima Martinelli²

Objective: The objective of this study was to evaluate a sagittal variation on the lower incisors with the use of the lingual arch on the transition from mixed to permanent dentition. Methods: The sample was constituted of 44 Caucasian patients (26 girls and 18 boys), divided in two groups: CG, control group, monitoring the lower arch space with no orthodontic/ orthopedic treatment during the rated period $(\mathrm{n}=14)$; EG, experimental group, presenting anterior inferior mild crowding and installation of the lingual arch for space maintenance $(n=30)$. The position of the lower incisors was analyzed on computerized cephalometric tracings performed at the beginning of the monitoring $\left(\mathrm{T}_{1}\right)$ and at the end, on the permanent dentition $\left(T_{2}\right)$. In order to evaluate the position of the incisors it was used Tweed and Steiner measurements: IMPA, 1.NB and 1-NB. The alterations were analyzed through the "t" test for paired samples, while the differences between the groups were analyzed through the " $\mathrm{t}$ " test for independent samples, as for sexual dimorphism. Results: The values in $\mathrm{T}_{2}$ were greater in relation to $\mathrm{T}_{1}$ for all measurements on $\mathrm{EG}$ (IMPA, $\mathrm{p}=0.038 ; 1 \mathrm{NB}, \mathrm{p}=0.007$ and $1-\mathrm{NB}, \mathrm{p}<0.0001$ ). On comparing the differences $\left(T_{2}-T_{1}\right)$ between $C G$ and $E G$, it can be gauged differences significantly superior for measure 1.NB $(p=0.002)$ and $1-N B(p<0.0001)$ on EG. There was no statisticaly significant difference between genres. Conclusion: It was concluded that the lower incisors were projected after using the lingual arch to control the space on the transition from mixed to permanent dentition, however, within acceptable standards, not having difference between genres.

Keywords: Incisor. Orthodontics. Cranial circumference.

Objetivo: avaliar a alteração sagital ocorrida nos incisivos inferiores com o uso do arco lingual no período de transição da dentição mista para a permanente. Métodos: a amostra foi composta por 44 pacientes leucodermas (26 meninas e 18 meninos), divididos em dois grupos: (GC) grupo controle, no qual foi efetuado monitoramento do espaço da arcada inferior, sem tratamento ortodôntico/ortopédico no período avaliado ( $\mathrm{n}=14)$; (GE) grupo experimental, presença de suave apinhamento anteroinferior e instalação do arco lingual para manutenção do espaço $(\mathrm{n}=30)$. A posição dos incisivos inferiores foi analisada em traçados cefalométricos computadorizados realizados ao início $\left(\mathrm{T}_{1}\right)$ e ao final do acompanhamento, já na dentição permanente $\left(\mathrm{T}_{2}\right)$. Para avaliar a posição dos incisivos foram utilizadas as medidas das análises cefalométricas de Tweed e de Steiner: IMPA, 1.NB e 1-NB. As alterações ocorridas foram analisadas pelo teste $t$ para amostras pareadas, enquanto as diferenças entre os grupos foram avaliadas pelo teste $t$ para amostras independentes, bem como para o dimorfismo sexual. Resultados: os valores em $T_{2}$ foram maiores em relação a $T_{1}$ para todas as medidas no GE (IMPA, $\mathrm{p}=0,038 ; 1 \cdot \mathrm{NB}, \mathrm{p}=0,007 ;$ e 1-NB, $\mathrm{p}<0,0001)$. Na comparação das diferenças $\left(\mathrm{T}_{2}-\mathrm{T}_{1}\right)$ entre o GC e GE pôde-se aferir diferenças significativamente superiores para as medidas 1 . NB $(p=0,002)$ e 1-NB $(p<0,0001)$ no GE. Não houve diferença significativamente estatística entre os sexos. Conclusão: concluiu-se que os incisivos inferiores foram projetados após a utilização do arco lingual para o controle do espaço no período de transição da dentição mista para a permanente, porém a projeção esteve dentro dos padrões aceitáveis, não havendo diferença entre sexos.

Palavras-chave: Incisivo. Ortodontia. Circunferência craniana.

» The authors report no commercial, proprietary or financial interest in the products or companies described in this article.

${ }^{1}$ Specialist in Orthodontics, PUCRS

${ }^{2}$ Professor at the Post-Graduation Course in Orthodontics and Facial Orthopedics, PUCRS.

${ }^{3} \mathrm{MSc}$ in Orthodontics and Facial Orthopedics, PUCRS.
How to cite this article: Letti HCB, Rizzatto SMD, Menezes LM, Reale CS, Lima EM, Martinelli FL. Sagittal changes in lower incisors by the use of lingual arch. Dental Press J Orthod. 2013 May-June;18(3):29-34.

Submitted: January 28, 2009 - Revised and accepted: April 27, 2011

» The patients displayed in this article previously approved the use of their facial and intraoral photographs.

Contact address: Helen Carolina Becker Letti

Av. Ipiranga, 6681 Prédio 6, Faculdade de Odontologia - Brazil

Bairro Partenon - Porto Alegre/RS - CEP: 90619-900 - Email: smdr@uol.com.br 


\section{INTRODUCTION}

The origin of the lingual arch was assigned by Dewey ${ }^{3}$ to Dr. Lourie in 1904, however, Mershon ${ }^{14,15}$ was the responsible for the popularization of the referred appliance. Originally it was used to expand the lower arch and posteriorly Nance ${ }^{16,17}$ described the indication of the lingual arch for the treatment on mixed dentition, suggesting its use only on the maintenance of the distance between permanent incisors and molars in specific cases.

The lingual arch, as an appliance of passive application, similar to the recommended by Nance, ${ }^{16}$ is widely used in orthodontic clinics until the present day. Its main utility is on controlling the perimeter of the lower arch, maintaining the distance between the first permanent molars and the lower incisors after the loss of deciduous molars. It can also be used as assistant for intraoral anchorage on the permanent dentition, from the mixed dentition. This type of appliance shows efficiency on the maintenance of the lower arch perimeter, preventing the molars movement to mesial and the incisors lingual inclination. ${ }^{22}$

The maintenance of the perimeter on the dentition development is fundamentally important because the use of the Leeway Space for eruption of premolars guarantees space for the correct alignment of the lower teeth in up to $80 \%$ of the patients with mild crowding. ${ }^{1,6,10,18}$

If not provided with adequate space for alignment of the permanent teeth, it may be necessary a less conservative conduct when the corrective orthodontic treatment is performed.

This way, the lingual arch installed on appropriate moment can reduce the number of future premolars extraction, lower arch stripping and other procedures to restore the space for adequate alignment of teeth. ${ }^{6}$

The cognition about the effects of the lingual arch on these teeth represents a necessity on the orthodontic practice, being an appliance of wide clinical utilization. The purpose of this study was to evaluate the sagittal variation on lower incisors due to utilization of lingual arch on the transition from mixed dentition to permanent.

\section{MATERIAL AND METHODS}

The present study comprehended 44 Caucasian patients (26 girls and 18 boys) in need of supervision of the space on the mixed dentition. The transition period from mixed dentition to permanent was monitored in two ways: Control group (CG, $n=14)$, space monitoring with no orthodontic/orthopedic treatment during the rated period; Experimental group (EG, $n=30)$, presenting anterior inferior mild crowding and installation of the lingual arch, previously to exfoliation of deciduous second molar, for space maintenance (Fig 1A).

The lingual arch appliance was made with stainless steel wire $0.9 \mathrm{~mm}$ (Morelli, Sorocaba/SP) outlining the incisal third of the lower incisors crown. The appliance was attached with glass ionomer cement (3M Unitek, CA/USA) in all patients from the experimental group (Fig 1B).

In the individuals from the control group it were performed lateral radiographs in two-step with a mean age of 9.7 years in $T_{1}( \pm 1.6)$ and 11.6 years in $T_{2}( \pm 1.3)$. In the patients from the EG, it were also performed two radiographs, in $\mathrm{T}_{1}$ obtained with mean age of 9.3 years $( \pm 1.1)$ and $T_{2}$ with mean age of 11.9 years $( \pm 1.1)$.

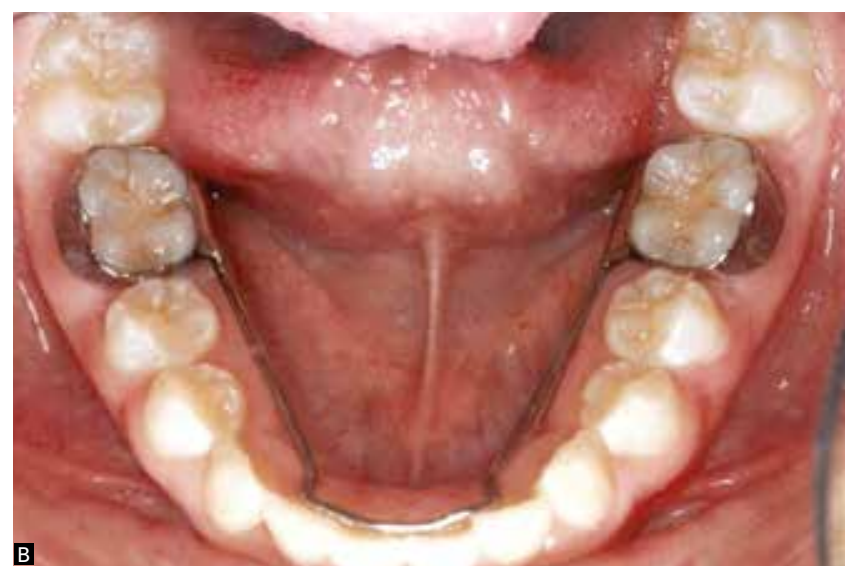

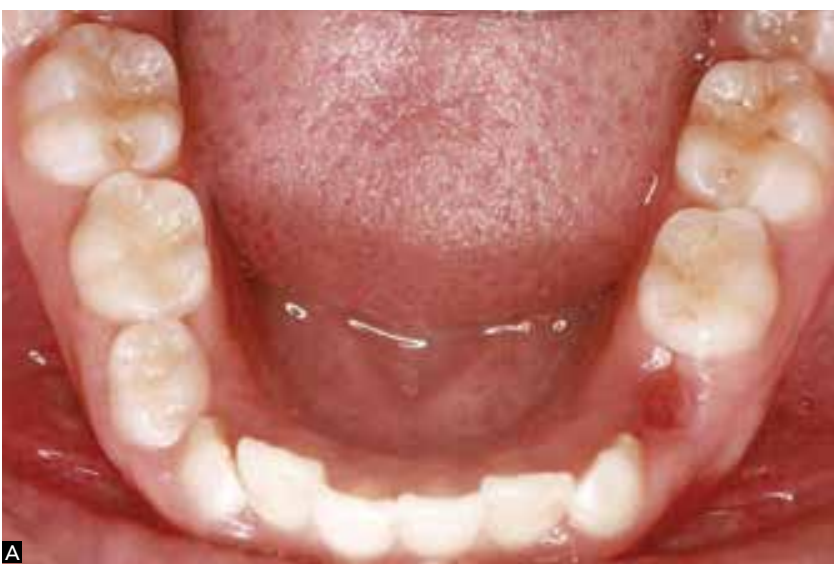

Figure 1 - A) $T_{1}$ : mixed dentition, previously to installation of the lingual arch. B) $T_{2}$ : young permanent dentition with lingual arch installed. 
Computerized cephalometric tracings were obtained from the Ortoview 2.5 software and analyzed at the beginning of the monitoring $\left(\mathrm{T}_{1}\right)$ and at the end, after eruption of permanent canines and premolars $\left(T_{2}\right)$, with lingual arch still installed (Figs $2 \mathrm{~A}$ and $2 \mathrm{~B}$ ). In order to evaluate the sagittal variations of the incisor it was used Tweed ${ }^{22,23,24}$ and Steiner ${ }^{19}$ measurements:

"IMPA: angle between the long axis of the lower incisor and the base of the mandible (line joining the point "Me" and the "lower portion on the back of the mandible base") - Tweed's analysis;

"1.NB: angle between the long axis of the lower incisor and the line NB - Steiner's analysis;

"1-NB: linear distance $(\mathrm{mm})$ between the most prominent portion of the lower incisor crown and line NB - Steiner's analysis.

Initially, it was performed a study of error. The measurements were redone by the same operator and compared through Student's $t$ test for paired samples. There was no significant difference between the values of the 1 st and the 2 nd measurement for the evaluated measures $(p>0.05)$.

The data were, then, collected and statistically analyzed comparing $\mathrm{T}_{1}$ to $\mathrm{T}_{2}$, evaluating the difference between genres and the difference between the two groups. The data were organized in tables and graphics, with mean values and standard deviation for period $T_{1}$ and $T_{2}$. To compare the two periods it was used the Student's t test for paired data. To evaluate the difference between genres and on comparing the two groups (experimental and control) it was used the Student's $t$ test for independent samples. The results were considered significant in a maximum level of significance of $5 \%$. To verify the normality of the data it was used the Kolmogorov-Smirnov non-parametric test, concluding that they have normal distribution.

\section{RESULTS}

The obtained results revealed significant differences between periods $T_{1}$ and $T_{2}$ in relation to the position of the lower incisors in the experimental group. In this group, it was noticed increasing values in $\mathrm{T}_{2}$ to the linear measure $1-\mathrm{NB}(\mathrm{p}=0.000)$, as to the angular measures $1 . \mathrm{NB}(\mathrm{p}=0.007)$, IMPA $(\mathrm{p}=0.038)$ (Table 1$)$.

The data show the projection on the lower incisors with the utilization of the passive lingual arch. On $E G$, in $T_{2}$, over $40 \%$ of the patients presented normal variation to the angular measure IMPA and 85\% did not exceeded $100^{\circ}$ (Fig 3). In the control group (CG), there was no significant difference between $T_{1}$ and $\mathrm{T}_{2}$ to any of the evaluated measures, according to Table 1. On comparing the differences $\left(\mathrm{T}_{1}-\mathrm{T}_{2}\right)$ between the control group and the experimental group, it can be gauged differences significantly superior on experimental group for measure $1 . \mathrm{NB}(\mathrm{p}=0.002)$ and $1-\mathrm{NB}(\mathrm{p}<0.000)($ Table 1$)$. There was no significant difference between genres to the evaluated measures (Tables 2 and 3).
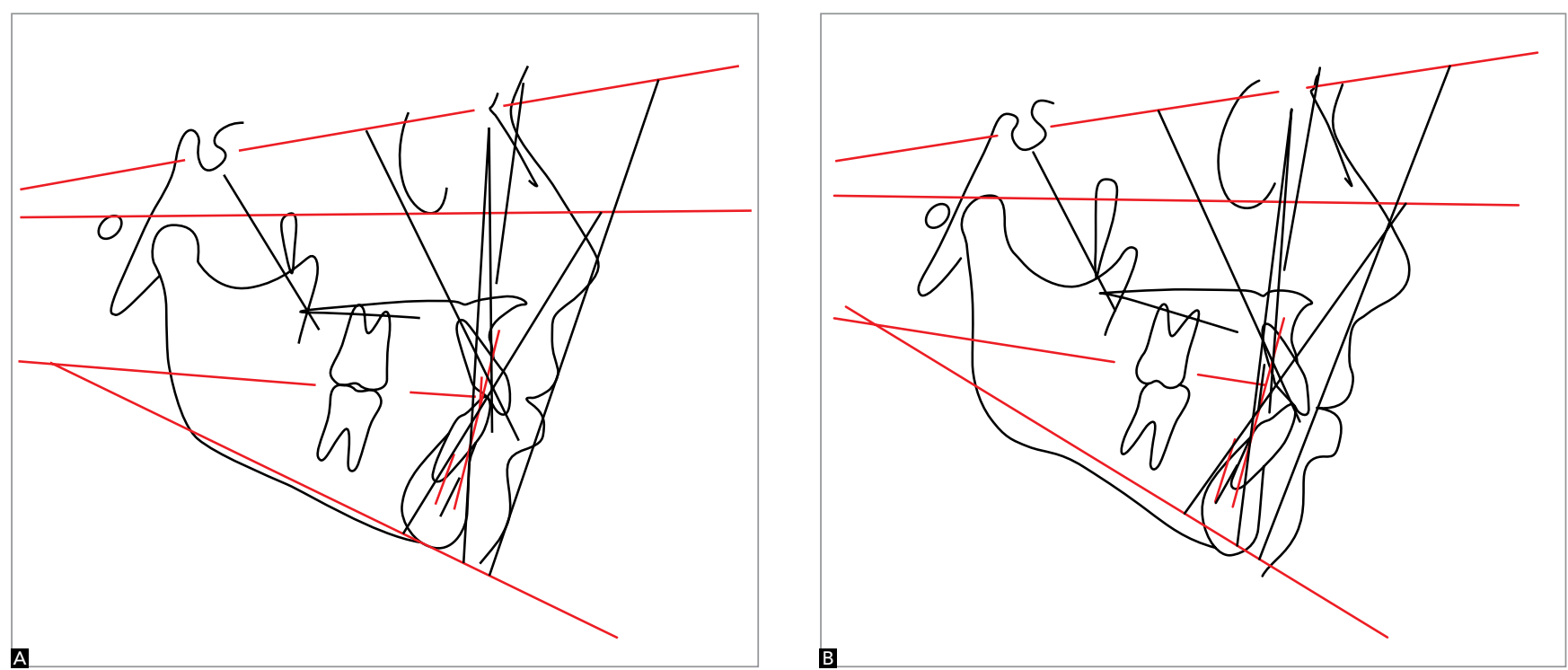

Figure 2 - A) Cephalometric tracing at $T_{1}$ : previously to installation of the lingual arch. B) Cephalometric tracing at $T_{2}$ : young permanent dentition with lingual arch still installed. 
Table 1 - Means, mean differences and t test comparing the groups.

\begin{tabular}{lccccc}
\hline & $\mathrm{T}_{1}$ & $\mathrm{~T}_{2}$ & ${ }^{*} \mathrm{p}$ & $\mathrm{T}_{2}-\mathrm{T}_{1}$ & ${ }^{*} \mathrm{p}$ \\
IMPA (CG) & 94.8 & 94.2 & 0.468 & -0.6 & \multirow{2}{*}{0.083} \\
IMPA (EG) & 92.9 & 94.8 & 0.038 & 1.9 & \\
\hline 1.NB (CG) & 26.7 & 25.9 & 0.163 & -0.8 & \multirow{2}{*}{0.002} \\
1.NB (EG) & 27.1 & 29.8 & 0.007 & 2.7 & \\
1-NB (CG) & 4.9 & 5.1 & 0.669 & 0.2 & \multirow{2}{*}{0.000} \\
1-NB (EG) & 5.1 & 6.7 & 0.000 & 1.6 & \\
\hline
\end{tabular}

${ }^{*} p$ value: Paired sample; ${ }^{* *} p$ value: Independent samples.

Table 2 - EG: Mean differences \pm standard deviation and t test comparing genders.

\begin{tabular}{ccccc}
\hline & \multicolumn{4}{c}{ Mean differences $\mathrm{T}_{2}-\mathrm{T}_{1}$} \\
& $\mathrm{n}$ & $\begin{array}{c}1-\mathrm{NB} \\
(\mathrm{mm})\end{array}$ & $\begin{array}{c}1 . \mathrm{NB} \\
\text { (degrees) }\end{array}$ & $\begin{array}{c}\text { IMPA } \\
\text { (degrees) }\end{array}$ \\
\hline Feminine & 19 & $1.5 \pm 1.1$ & $1.6 \pm 4.6$ & $1.1 \pm 4.8$ \\
Masculine & 11 & $2.0 \pm 1.2$ & $4.7 \pm 5.6$ & $3.6 \pm 5.2$ \\
${ }^{*} \mathrm{p}$ & & 0.258 & 0.118 & 0.186 \\
\hline
\end{tabular}

*p value: Independent samples.

Table 3 - CG: Mean differences \pm standard deviation and t test comparing genders.

\begin{tabular}{ccccc}
\hline & \multicolumn{4}{c}{ Mean differences $\mathrm{T}_{2}-\mathrm{T}_{1}$} \\
& $\mathrm{n}$ & $\begin{array}{c}\text { 1-NB } \\
(\mathrm{mm})\end{array}$ & $\begin{array}{c}\text { 1.NB } \\
\text { (degrees) }\end{array}$ & $\begin{array}{c}\text { IMPA } \\
\text { (degrees) }\end{array}$ \\
\hline Feminine & 7 & $-0.1 \pm 0.3$ & $-0.4 \pm 2.2$ & $-0.1 \pm 2.6$ \\
Masculine & 7 & $0.2 \pm 1.2$ & $-1.2 \pm 1.9$ & $-1.1 \pm 3.0$ \\
${ }^{*} \mathrm{p}$ & & 0.507 & 0.455 & 0.546 \\
\hline
\end{tabular}

*p value: Independent samples.

\section{DISCUSSION}

The length of the arch, as well as its perimeter, is reduced on the transition from mixed dentition to permanent, especially on the mandibular arch. This reduction on the arch perimeter is basically due to a mesial migration of the first permanent molar after the loss of the second deciduous molar. ${ }^{7}$ The lingual arch shows efficiency on the maintenance of the lower arch perimeter, that is, preventing the molars movement to mesial and the linguoversion of the incisors, fact that can be associated to the reduction of mandibular crowding. ${ }^{2,25}$ It allows the lower incisors to take an appropriate position by the perioral musculature and intraoral functional forces. Singer ${ }^{19}$ noticed distal inclination of lower molar, tendency (not significant) to projection of incisors and a greater tendency of the incisors and molars to present smaller vertical development in patients treated with lingual arch.
Morphological variations in the symphysis mentalis region, due to growth, result in modifications on the position of lower incisors. The cognition of these variations is of great clinical importance, being fundamental data on orthodontic planning. ${ }^{8,11}$ According to Enlow, ${ }^{5}$ as regards to lower incisors, there is a physiological remodeling on the alveolar region, causing a lingual inclination. The lower dental arch is referenced as one of the main elements for the diagnosis and for the orthodontic therapy. The dental positions will be established basically by the bone configuration, that is, the teeth should be aligned on the alveolar ridge. ${ }^{21}$

Tweed, ${ }^{22}$ through his studies, suggested the inclination of the lower incisors in relation to the mandibular ridge of $90^{\circ}$ with a variation of $5^{\circ}$ for further or for fewer, creating the IMPA, first angle of what would be the diagnostic facial triangle. Posteriorly, the same author, found the norm of $87^{\circ}$ to the angular measure IMPA with variation from $76^{\circ}$ to $99^{\circ}$ on the studied sample. ${ }^{23,24}$ In the experimental group (in $\mathrm{T}_{2}$ ), in relation to this angle, over $40 \%$ of the patients are within the normal variation and $85 \%$ did not exceeded $100^{\circ}$ (Fig 3), being these values considered according to acceptable standard of normality and the minimum value found of $82.5^{\circ}$ and the maximum of $106^{\circ}$.

Steiner ${ }^{20}$ suggested angular and linear mean values to the position of lower incisors in relation to line NB considered as standard, being $25^{\circ}$ to $1 . \mathrm{NB}$ and $4 \mathrm{~mm}$ to $1-\mathrm{NB}$. In this study, in $\mathrm{T}_{2}$, to the angular measure $1 . \mathrm{NB}$ the minimum value found was $18.8^{\circ}$ and the maximum was $36.6^{\circ}$. To the linear measure, $1-\mathrm{NB}$, the values were $3.6 \mathrm{~mm}$ and $11.3 \mathrm{~mm}$, being respectively minimum and maximum. However, values conventionally adopted as representative of normality not always can be used indistinctly, given that variation due to growth and craniofacial development are characteristic of different organisms. ${ }^{11}$

The normal mandibular growth tend to increase the SNB, with greater progress attributed to point $\mathrm{B}$, since the point $\mathrm{N}$ does not progresses with the same intensity, altering the geometric relation of the line $\mathrm{NB}$ with the long axis of the lower incisor, with artificial reduction of $1 . \mathrm{NB}$ and $1-\mathrm{NB}$. Therefore, the IMPA presents more reliable value for the analysis of the lower incisor position, since it experiences less 


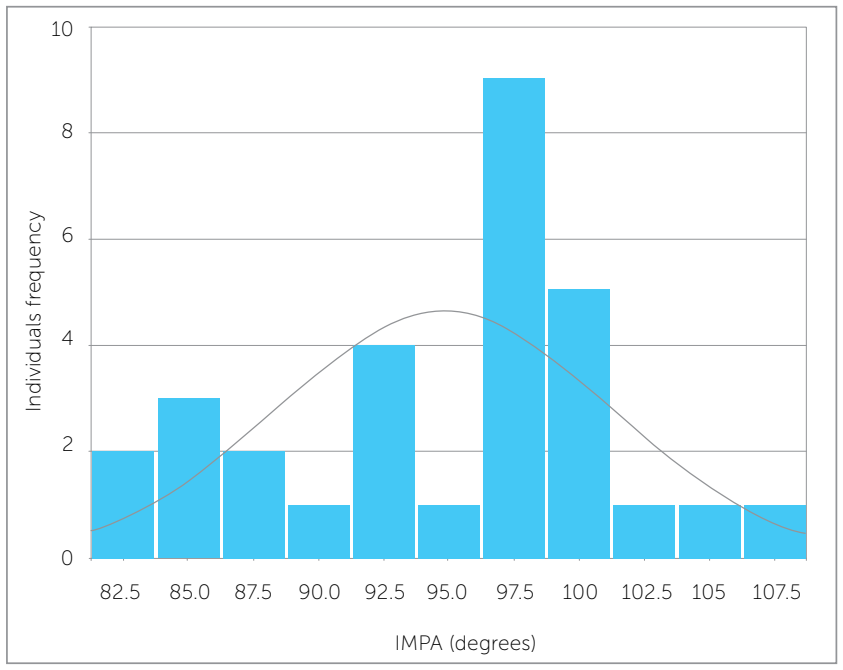

Figure 3 - IMPA (Experimental Group): final value.

influence of the mandibular growth. Aiming to determine accurately the inclination of the lower incisors, the measures 1.NB, 1-NB and IMPA were used with reference in this work.

The variations on point $\mathrm{B}$ occur smoothly from 6 to 10 years and well-marked from 10 to 15 years, concomitantly with the lingual inclination of incisors. ${ }^{8}$ In agreement to the previous study, Watanabe et $\mathrm{a}^{26}$ also verified a lingual inclination of mandibular incisors between 8 and 15 years old. During puberty, therefore, the lower incisors tend to move lingual, if nothing prevents this movement. If the lingual inclination does not occur, this can be attributed to crowding in the anterior region.

According to the results found in this study, the use of the lingual arch prevented the tendency of lingual inclination reported on previous studies, being observed some projection of lower incisors. The projection of the lower incisors verified in this study can be considered clinically advantageous, noting that minimizes or even eliminates the necessity of future extractions or stripping during the treatment in cases of small negative discrepancies on the mixed dentition and depending of the cephalometric and facial interpretation, of the complaint of the patient and of what is biologically acceptable in each individual.

This projection can be used, facilitating orthodontic biomechanical with gain of space. ${ }^{27}$ The orthodontic intervention on mixed dentition would promote smaller chances of development of future occlusal problems. ${ }^{9}$ Besides the maintenance of the Leeway space, using the lingual arch is possible to restore space in up to $2 \mathrm{~mm}$ of negative discrepancy, eliminating the crowding on the transition from mixed dentition to permanent when it is presented. ${ }^{10}$

Dugoni et $\mathrm{al}^{4}$ verified that using the lingual arch on alignment of lower incisors was clinically acceptable in $76 \%$ of the cases on the post-restraint period. According to the same authors, the use of the Leeway space to dissolution of crowding may result in better stability in long-term. ${ }^{4}$ The methods usually adopted to calculate the discrepancy in the analysis of the mixed dentition can overestimate the values obtained. It is suggested, therefore, the utilization of size prediction methods of permanent teeth that have a coefficient of explanation $\left(\mathrm{R}^{2}\right)$ closer to 1 . For this, the utilization of oblique teleradiograph of $45^{\circ}$ is an option with good degree of accuracy. ${ }^{12,13}$

Rabellato et $\mathrm{al}^{18}$ reported a slight projection of the lower incisors, finding a mean value of increase on IMPA of $0.73^{\circ}$, having evaluated 14 patients with mean age of 11.5 years, that used only passive lingual arch in this period of the treatment, using the overlay method of cephalometric tracings for comparison pre and post-treatment.

Villalobos ${ }^{24}$ reported that the lower incisor presented a discrete retroclination of $0.52^{\circ}$, on average, using the lingual arch through the same overlay method of cephalometric tracings. Despite the methodological difference about the comparison between the initial and the final position of the lower incisors, in the present study it was found a mean projection of $1.9^{\circ}$ for the IMPA. The option for using computerized cephalometric tracings with angular and linear measures was based on standardization of the technique, allowing longitudinal evaluations of the same individual with good reliability degree.

\section{CONCLUSION}

It was concluded that the lower incisors were projected after using the lingual arch to control the space on the transition from mixed dentition to permanent, however within acceptable standards, not having statistic difference between genres for the evaluated measures. 


\section{REFERENCES}

1. Brennan MM, Gianelly AA. The use of the lingual arch in the mixed dentition to resolve crowding. Am J Orthod Dentofacial Orthop. 2000;117(1):81-5

2. De Baets J, Chiarini M. The pseudo-Class I: a newly defined type of malocclusion. J Clin Orthod. 1995:29(2):73-88

3. Dewey $M$. The lingual arch in combination with the labial arch with extensions as used by Dr. Lloyd S. Lourie. Int J Orthod. 1916:2(10):563-602

4. Dugoni SA, Lee JS, Varela J, Dugoni AA. Early mixed dentition treatment: postretention evaluation of stability and relapse. Angle Orthod. 1995:65(5):311-20.

5. Enlow DH. O processo do crescimento facial. In: Crescimento facial. 3a ed. São Paulo: Artes Médicas; 1993. p. 72-3

6. Gianelly AA. Crowding: timing of treatment. Angle Orthod. 1994; 64(6):415-8.

7. Gianelly AA. Treatment of crowding in the mixed dentition. Am J Orthod Dentofacial Orthop. 2002;121(6):569-71.

8. Jones JD. The eruption of the lower incisor and the accompanying development of the symphysis and point B. Angle Orthod. 1966:36(4):358-62.

9. Keski-Nisula K, Hernesnieme R, Heiskanen M, Keski-Nisula L, Varrela J. Orthodontic intervention in the early mixed dentition: A prospective, controlled study on the effects of the eruption guidance appliance. Am J Orthod Dentofacial Orthop. 2008:133(2):254-60.

10. Letti HCB, Braga FL, Lima EMS. $O$ arco lingual na transição da dentição mista para a dentição permanente. Ortod Gaúch. 2005:9(2):122-6.

11. Marques JS, Siqueira VCV. Estudo das alterações do ponto B durante o tratamento ortodôntico. Rev Dental Press Ortod Ortop Facial. 2007:12(3):136-45

12. Martinelli F, Lima EM, Rocha R, Tirre-Araujo MS. Prediction of lower permanent canine and premolars width by correlations methods. Angle Orthod. 2005:75(5):805-8

13. Melgaço CA, de Sousa Araújo MT, de Oliveira Ruellas AC. Mandibular permanent first molar and incisor width as predictor of mandibular canine and premolar width. Am J Orthod Dentofacial Orthop. 2007:132(3):340-5
14. Mershon JV. Band and lingual arch technique. Int J Orthod. 1917:3:195-203

15. Mershon JV. The removable lingual arch as an appliance for the treatment of malocclusion of the teeth. Int J Orthod. 1918:4:578-87.

16. Nance HN. The limitations of orthodontics treatment: I, mixed dentition diagnosis and treatment. Am J Orthod. 1947 Apr;33(4):177-223.

17. Nance HN. The limitations of orthodontics treatment: II, diagnosis and treatment in the permanent dentition. Am J Orthod. 1947:33:253-301.

18. Rebellato J, Lindauer SJ, Rubenstein LK, Isaacson RJ, Davidovitch M, Vroom K. Lower arch perimeter preservation using the lingual arch. Am J Orthod Dentofacial Orthop. 1997:112(4):449-56.

19. Singer $\mathrm{J}$. The effect of the passive lingual archwire on the lower denture. Angle Orthod. 1974;44(2):146-55

20. Steiner CC. Cephalometrics for you and me. Am J Orthod. 1953:39(10):729-55

21. Triviño T, Siqueira DF, Scanavini MA. A forma do arco dentário inferior na visão da literatura. Rev Dental Press Ortod Ortop Facial. 2007:12(6):61-72

22. Tweed $\mathrm{CH}$. A philosophy of orthodontic treatment. Am J Orthod 1945:31(2):74-103

23. Tweed $\mathrm{CH}$. The Frankfort-Mandibular Incisor Angle (FMIA). In: Orthodontic diagnosis, treatment, planning and prognosis. Am J Orthod 1954;24(3):74-103

24. Tweed $\mathrm{CH}$. Was the development of diagnosis facial triangle as an accurate analysis based on fact or fancy? Am J Orthod. 1962; 48(11):823-40

25. Villalobos FJ, Sinha PK, Nanda RS. Longitudinal assessment of vertical and sagittal control in the mandibular fixed lingual arch. Am J Orthod Dentofacial Orthop. 2000:118(4):366-70.

26. Watanabe E, Demirjian A, Buschang P. Longitudinal post-eruptive mandibular tooth movements of males and females. Eur J Orthod. 1999:21(5):459-68

27. Zanelato ACT, Trevisi HJ, Zanelato RCT, Zanelato ACT, Trevisi RC. Análise da movimentação dentária (VTO dentário). Rev Clín Ortod Dental Press. 2006:5(5):59-65 